\title{
STOP 15: Morphology and internal structure of a ribbed moraine and drumlin remnant in the environs of Baldone, Central Latvian Lowland
}

Kristaps Lamsters and Vitālijs Zelčs

University of Latvia

Mašēni and Aizvējas are two sand pits located on a composite angular-shaped hummock with a relative height of up to $40 \mathrm{~m}$ and an extent of approximately $1.5 \times 1.7 \mathrm{~km}$ (Fig. 15.1). The NE part resembles a remnant of a drumlin, oriented parallel to the regional ice flow direction (NNW-SSE). The Aizvējas sand pit $\left(24^{\circ} 20^{\prime} 12^{\prime \prime} \mathrm{E}, 56^{\circ} 46^{\prime} 17^{\prime \prime} \mathrm{N}\right)$ is located on this drumlin-like ridge, whereas the Mašeni sand pit $\left(24^{\circ} 20^{\prime} 19^{\prime \prime} \mathrm{E}, 56^{\circ} 45^{\prime} 32^{\prime \prime} \mathrm{N}\right)$ is located on the ribbed moraine ridge. The overall morphology of the Zemgale ribbed moraines is characterized by two sets of ridges that are perpendicular to each other, caused by ribbed moraine superimposition on drumlins (Zelčs 1993; Zelčs and Dreimanis 1998), but more complex landforms are found in the NE part of the Zemgale ribbed moraine field in the environs of Baldone (Lamsters and Ošs 2012). The Zemgale ribbed moraine area lies in the Upmale hummocky plain between the Iecava drumlin field in the west and the marginal formations of the North Lithuanian glacial phase, the so-called Valle ridge (Āboltiņš 1970), in the east. A number of ribbed moraines are also found on the Ropaži Plain, west of the Madliena drumlin field (Lamsters 2012).

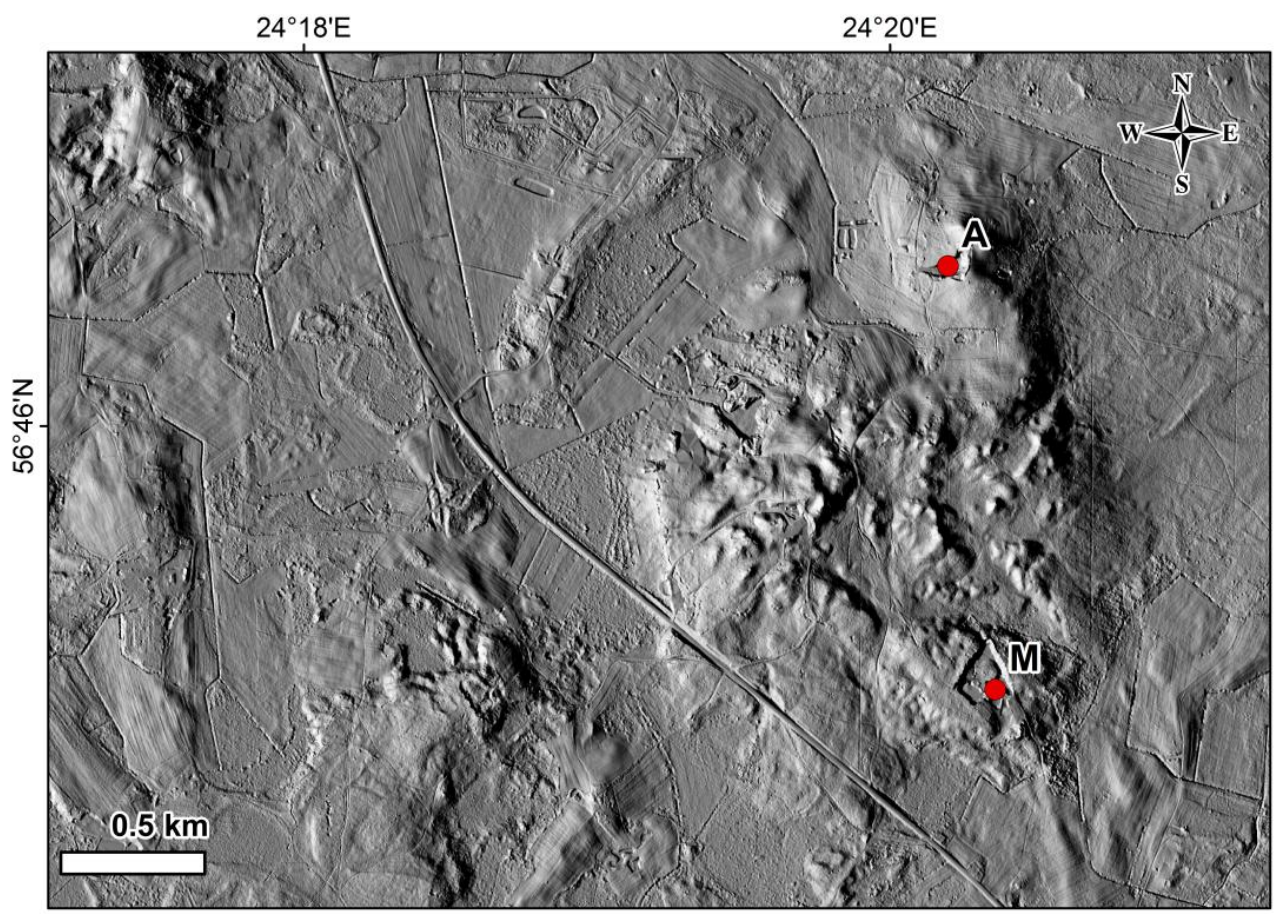

Fig. 15.1. Topography of the complex ribbed moraine ridge and drumlin remnant in the environs of Baldone. Relief-shaded DEM with grid size of $2 \mathrm{~m}$. Courtesy of METRUM Ltd.

In the Upmale hummocky plain the bedrock surface is composed of Upper Devonian Frasnian sedimentary rocks. Beneath the ribbed moraine under consideration the bedrock consists of dolomite and marl with interlayers of clay. Gypsum layers are also found closer to Baldone (Naumenko and Jankins 1999). In general the bedrock surface lowers in the $\mathrm{W}$ and NW direction from $40 \mathrm{~m}$ to $-5 \mathrm{~m}$ a.s.l. The Pleistocene cover is on average from a few metres up to $20 \mathrm{~m}$ thick, although it is thicker in some individual hummocks in the surroundings of Baldone, reaching a maximum of $45 \mathrm{~m}$. 

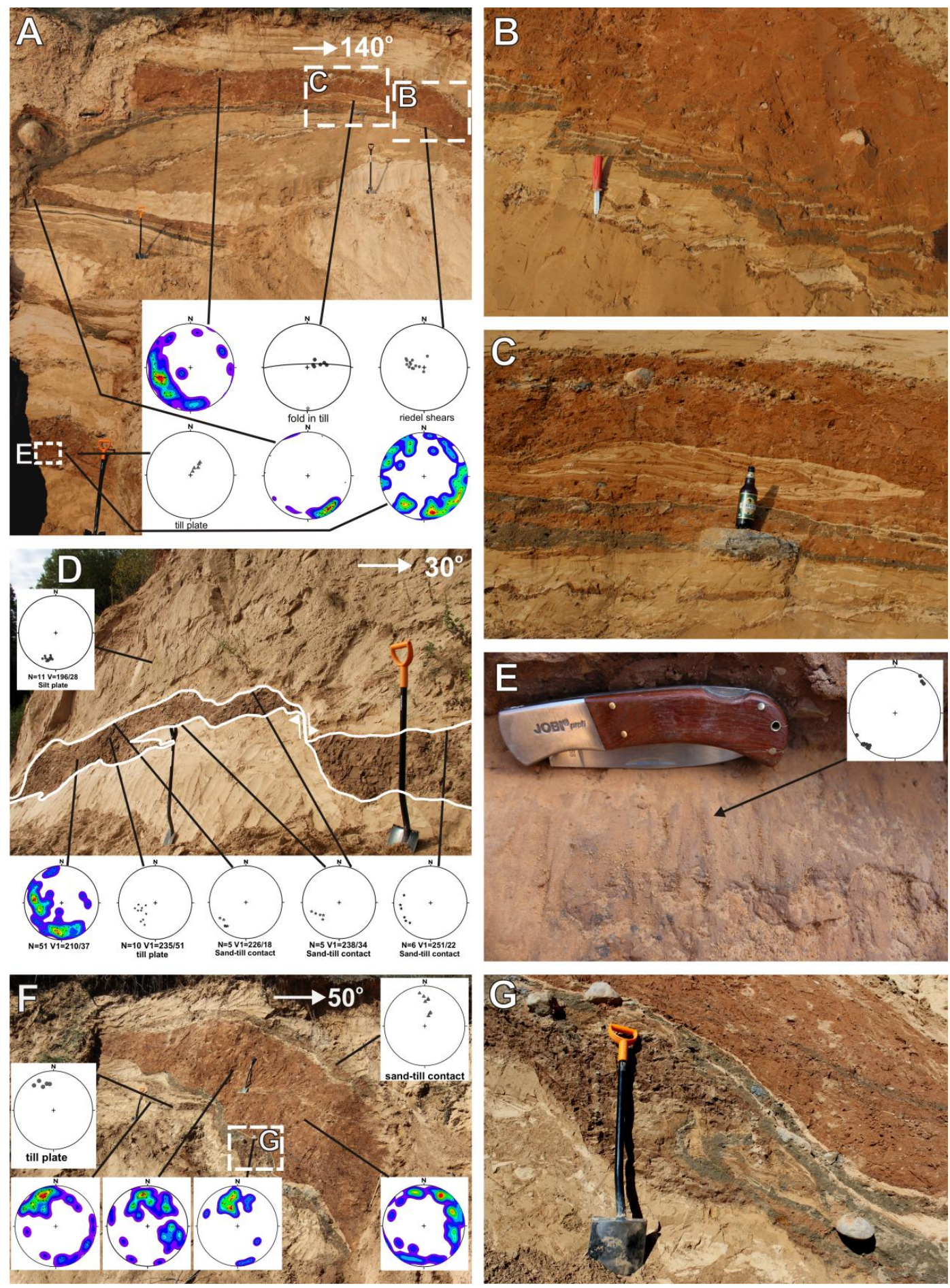

Fig. 15.2. Internal structure of the ribbed moraine in the Mašèni sand pit. A. View of the outcrop parallel to the ice-flow direction, with four distinct, different-coloured till beds. B. Small faults (Riedel shears) in the topmost till bed and underlying silty sediments; see location in Fig. 15.2A. C. Recumbent fold in the topmost till bed consisting of a mixture of sand/silt/diamictic material; see location in Fig. 15.2A. D. View of the outcrop transverse to the ice-flow direction with a sequence of deformed silt/diamictic/sand sediments. E. Internal slickenside in the lowermost till bed, showing a grooved surface; see location in Fig. 15.2A; F. View of the outcrop transverse to the ice flow direction, showing an obvious till thrust sheet; G. Close-up photograph of three different-coloured tills deformed together with underlying silt/sand; see location in Fig. 15.2F.

The Pleistocene sequence generally consists of at least two Weichselian till beds and sorted sediments between them, although observations of the internal structure of the ribbed moraines in the vicinity of Daugmales Tomēni provide evidence of up to five Weichselian till 
beds underlain by one or two possible Saalian till beds (Dreimanis 1935; Dreimanis and Zelčs 1995; Zelčs and Dreimanis 1998). Such a complicated and glaciotectonically disturbed structure is also observed in the Mašēni sand pit, where the Pleistocene sequence is made of at least four distinct till beds interbedded with deformed sorted sediments (Fig. 15.2A), and of one till bed at the base of the ribbed moraine. This structure most likely originated through successive subglacial thrusting under a compressional ice flow regime, as also reported by Stokes et al. (2008).

Three outcrops were investigated in detail in the Mašēni sand pit (Fig. 15.2). One of these is parallel (Fig. 15.2A) and the next two are transverse (Fig. 15.2D, F) to the former regional direction of the ice flow. The first outcrop is $11 \mathrm{~m}$ high and consists of four diamicton units interbedded with silt, silty and fine grained sand. This structure is interpreted as imbricated thrust sheets (Fig. 15.2A). The lower till bed is brown, densely compacted and brecciated, whereas the three upper beds are banded deformation tills consisting of differentcoloured layers. The upper part of the topmost diamicton bed is composed of reddish-brown till with greenish-grey till and sand intercalations at the bottom. It contains a recumbent fold with the hinge striking in a N-S direction (Fig. 15.2C), and faults that resemble Riedel shears (Fig. 15.2B). A very thin interlayer of deformed brown till is also found between the two upper tills (Fig. 15.2B, C). Three till fabric plots that were measured in different till beds have fabric maxima dipping towards WSW and SSE. The lineations (grooves) on the internal slickenside (Fig. 15.2E) in the lower till bed trend NE-SW. The measured structural data indicate variable ice stress directions. It is possible that the till fabric was re-oriented due to widespread glaciotectonic deformation, which is evident from abundant plastic and brittle deformation structures.

The first of the transverse outcrops (Fig. 15.2D) consists of 1-m-thick till in the upper part, which is underlain by up to $4 \mathrm{~m}$ thick silt and up to $1 \mathrm{~m}$ thick brown fissile till. This sequence is underlain by silty and fine-grained deformed sand. The structural measurements of till fabric, till plates, till and sand/silt contacts dip in the direction between $\mathrm{W}$ and S (Fig. 15.2D).

The second of the transverse outcrops is located in a 13-m-high wall. It consists of deformed fine sand and silt disrupted by a diamicton (Fig. 15.2F). It is up to $4 \mathrm{~m}$ thick, thinning towards the top. The diamicton is composed of the same three different coloured till layers as described previously. The thicker one is a reddish-brown, massive sandy till layer. The other tills are only a few centimetres to decimetres thick and underlie the reddish-brown till. The contacts between tills and sand/silt are very deformed - mixed together and folded (Fig. 15.2G). The greenish-grey till is characterized by a concentration of cobbles and boulders that dip to NNW. The plots of reddish-brown till macrofabrics and till plate also indicate the ice stress direction, from NNW, which coincides with the regional ice movement direction.

A 12-m-high outcrop striking N-S was investigated in the Aizvējas sand pit (Fig. 15.3A). It is composed of deformed fine/silty sand and silt overlain by 4 to $5 \mathrm{~m}$ thick massive, in the upper part fissile reddish brown subglacial till. The lower part of this till is deformed and contains sand inclusions and one upward-injected sand dyke (Fig. 15.3C). An ice wedge pseudomorph was found in the upper part of the till (Fig. 15.3B), indicative of permafrost conditions after glacier retreat.

The second outcrop consists of a 3-m-high section of deformed silt and sand sediments intercalated with five, up to $40 \mathrm{~cm}$ thick deformed diamicton layers (Fig. 15.3D). This sequence is underlain by a mixture of silt and sand with abundant dewatering and glaciotectonic deformation structures. Up to $0.5 \mathrm{~m}$ thick individual till beds are also found in the other parts of the sand pit. 

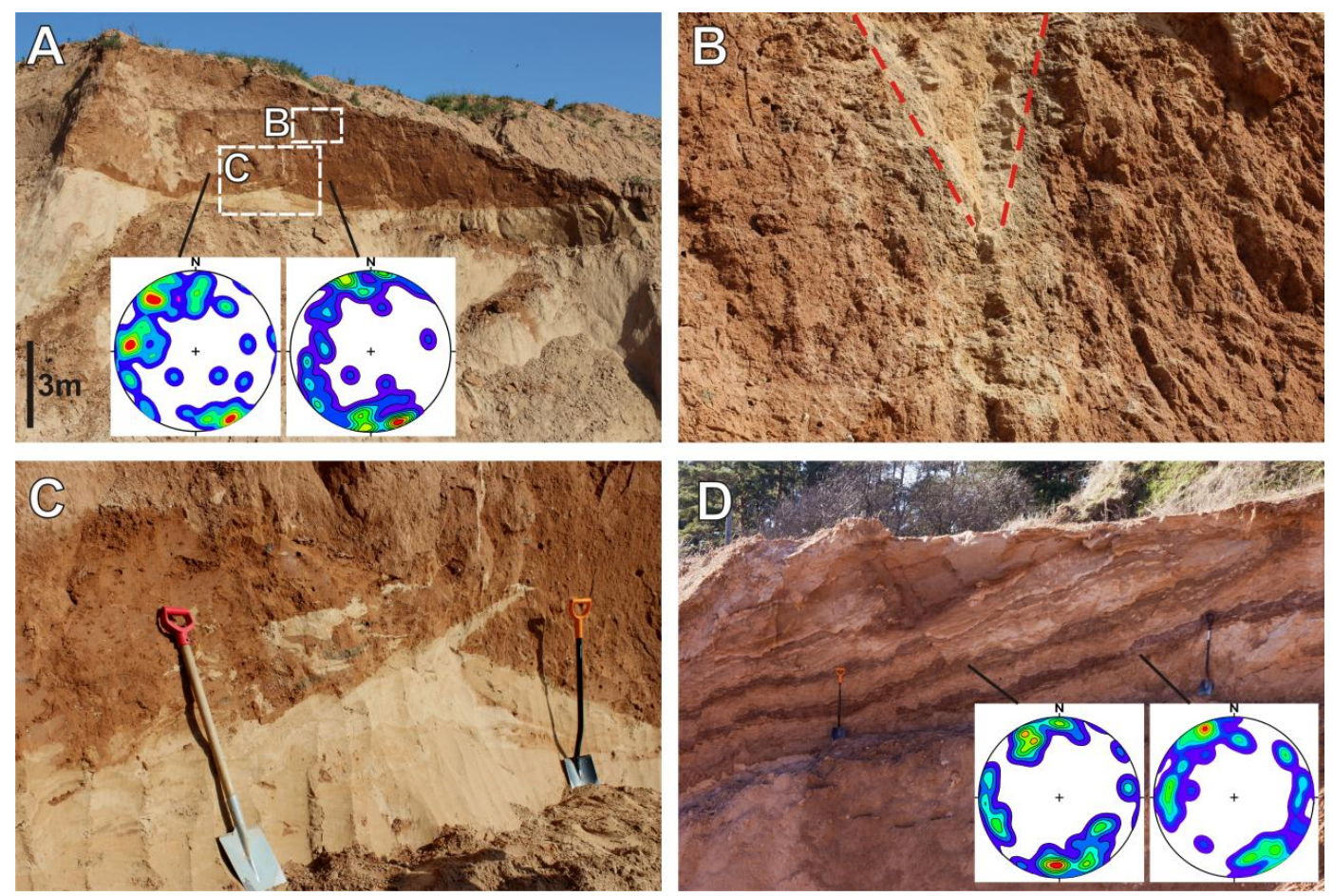

Fig. 15.3. Internal structure of the drumlin remnant in the Aizvējas sand pit: A. Outcrop consisting of 4-m-thick subglacial till underlain by deformed silt/sand sediments. B. Ice wedge pseudomorph in the upper part of the till; see location in Fig. 15.3A. C. Clastic dyke and sand inclusions in the lower part of the till; see location in Fig. 15.3A. D. Outcrop consisting of deformed silt and sand sediments intercalated with five deformed diamicton layers (up to $40 \mathrm{~cm}$ thick).

Till macrofabrics were measured at two spots in each of two outcrops (Fig. 15.3 A, D). All macrofabrics are multimodal but with a more expressed NNW-SSE trend, which corresponds to the regional ice flow movement, and additional maximums in three plots pointing to the west. It is most likely that the till fabric in these outcrops, too, especially in the second one (Fig. 15.3D), reflects a multiplex deformation pattern.

\section{References}

Dreimanis, A. 1935. The rock deformations, caused by inland ice, on the left bank of Daugava at Dole Island, near Riga in Latvia. Rīga, Gulbis, 30 pp. (In Latvian, with English summary)

Dreimanis, A., Zelčs, V. 1995. Pleistocene stratigraphy of Latvia. In: Ehlers, J., Kozarski, S., Gibbard, P. (eds.), Glacial Deposits in North-East Europe. Balkema, Rotterdam/Brookfield, pp. 105-113.

Lamsters, K. 2012. Drumlins and related glaciogenic landforms of the Madliena Tilted Plain, Central Latvian Lowland. Bulletin of the Geological Society of Finland, 84(1), 45-57.

Lamsters, K., Ošs, R. 2012. The distribution, morphology and internal structure of the Zemgale ribbed moraines, Central Latvian Lowland. In: Zelčs, V. (ed.-in chief), Acta Universitatis Latviensis. Earth and Environmental Sciences, 789. University of Latvia, pp. 52-65 (in Latvian, with English summary).

Naumenko, J., Jankins, J. 1999. Report on the results of the engineering and geological investigations of the perspective site „Mašēni” for the houshold and industrial waste dumpsite. SIA Geologiskais un geofiziskais centrs, Rīga, 78 pp. (In Latvian)

Stokes, C.R., Lian, O.B., Tulaczyk, S., Clark, C.D. 2008. Superimposition of ribbed moraines on a paleo-icestream bed: implications for ice stream dynamics and shutdown. Earth Surface Processes and Landforms, 33(4), 593-609.

Zelčs, V. 1993. Glaciotectonic landforms of divergent type glaciodepressional lowlands. Dissertation work synthesis. University of Latvia, Rīga, $105 \mathrm{pp}$.

Zelčs, V., Dreimanis, A. 1998. Daugmale ribbed moraine area: Introduction to STOP 1. Stop 1: Internal structure and morphology of glaciotectonic landforms at Daugmale. In: Zelčs, V. (ed.), Glacial Processes and Quaternary Environment in Latvia. Excursion guide of the INQUA Peribaltic Group Field Symposium, May 25-31, 1998, Rīga, Latvia. University of Latvia, Rīga, pp. 3-14. 

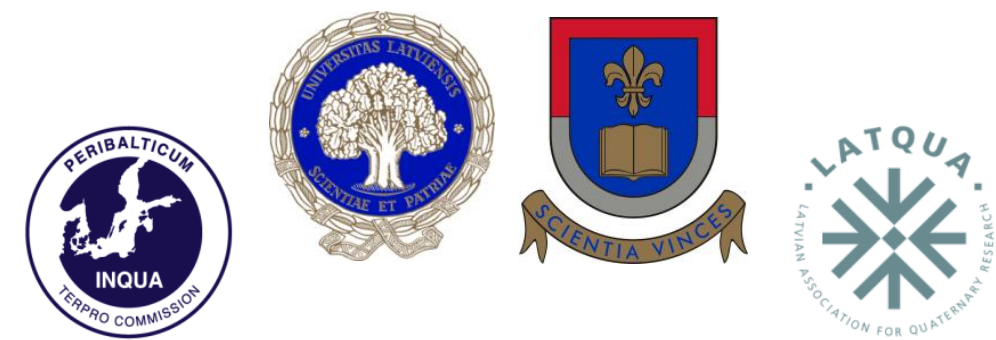

INQUA TERPRO COMMISSION PERIBALTIC WORKING GROUP

UNIVERSITY OF LATVIA

UNIVERSITY OF DAUGAVPILS

LATVIAN ASSOCIATION FOR QUATERNARY RESEARCH

\section{LATE QUATERNARY \\ TERRESTRIAL PROCESSES, SEDIMENTS AND HISTORY: FROM GLACIAL TO POSTGLACIAL ENVIRONMENTS}

EASTERN AND CENTRAL LATVIA

AUGUST 17-22, 2014 


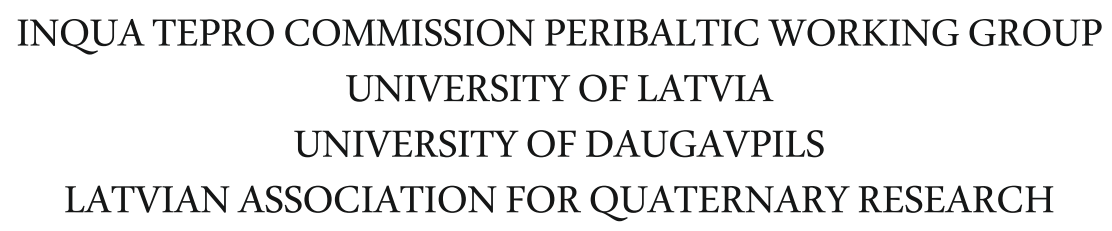

\title{
LATE QUATERNARY \\ TERRESTRIAL PROCESSES, SEDIMENTS AND HISTORY: FROM GLACIAL TO POSTGLACIAL ENVIRONMENTS
}

\author{
EASTERN AND CENTRAL LATVIA
}

AUGUST 16-22, 2014 
Organized by:

University of Latvia

Daugavpils University

Latvian Association for Quaternary Research

INQUA Peribaltic Working Group (INQUA TERPRO Commission)

Organizing committee:

Māris Nartišs (Chair, University of Latvia)

Māris Krievāns (Secretary, University of Latvia)

Aivars Markots (University of Latvia)

Juris Soms (Daugavpils University)

Evija Tērauda (University of Latvia)

Vitālijs Zelčs (University of Latvia)

Contributors:

Ivars Celiņš, Edgars Greiškalns, Ieva Grudzinska, Edyta Kalińska-Nartiša, Laimdota Kalniņa, Jānis Karušs, Māris Krievāns, Kristaps Lamsters, Aivars Markots, Māris Nartišs, Agnis Rečs, Normunds Stivriņš, Juris Soms, Ivars Strautnieks, Santa Strode, Sandra Zeimule, Vitālijs Zelčs

Editors: Vitālijs Zelčs and Māris Nartišs

The English texts of the field guide were revised by Valdis Bērziņš

Recommended reference for this publication:

Zelčs, V. and Nartišs, M. (eds.) 2014. Late Quaternary terrestrial processes, sediments and history: from glacial to postglacial environments. Excursion guide and abstracts of the INQUA Peribaltic Working Group Meeting and field excursion in Eastern and Central Latvia, August 17-22, 2014. University of Latvia, Rīga, 2014, 150 pages.

Sponsored by:

University of Latvia

Layout: Vitālijs Zelčs, Māris Nartišs and Māris Krievāns

ISBN 078-9934-517-60-0

(C) University of Latvia, 2014

This volume is available from:

Faculty of Geography and Earth Sciences

University of Latvia

Rainis Blvd. 19

Rìga, LV1586

Latvia 